\title{
Lipid Profile of Nutrition Students and its Association with Cardiovascular Disease Risk Factors
}

\author{
Regina Mara Fisberg, Roberta Horschutz Stella, Juliana Masami Morimoto, Luciana Sicca Pasquali, \\ Sonia Tucunduva Philippi, Maria do Rosário D. O. Latorre
}

São Paulo, SP - Brazil

\begin{abstract}
Objective - To describe the lipid profile and to verify its relationship with cardiovascular disease risk factors in students at a public university in São Paulo.
\end{abstract}

Methods - After obtaining clinical, anthropomorphic, and lipid profile data from 118 students, variables of the lipid profile were related to other risk factors.

Results - The mean age of the students was 20.3 years $(S D=1.5)$. The risk of cardiovascular disease was characterized by a positive family history of ischemic heart disease in 38.9\%; sedentariness in 35.6\%; limiting and increased total and LDL-C cholesterol levels in $17.7 \%$ and $10.2 \%$, respectively; decreased HDL-C levels in 11.1\%; increased triglyceride levels in $11.1 \%$; body mass index $>25$ in $8.5 \%$, and smoking in $6.7 \%$ of the subjects. Students' diet was found to be inadequate regarding protein, total fat, saturated fat, sodium, and fiber contents. A statistically significant association between cholesterol and contraceptive use, between HDL-C and contraceptive use, age and percent body fat, and triglycerides and percent lean weight was observed.

Conclusion - A high prevalence of some risk factors of cardiovascular disease as well as the association between these factors with altered lipid profiles was observed in the young population studied.

Key words: risk factors, lipid profile, cardiovascular disease, atherosclerotic disease

School of Public Health, University of São Paulo, SP, Brazil

Correspondência: Regina Mara Fisberg - Faculdade de Saúde Pública - Depto de Nutrição - Av. Dr. Arnaldo, 715 - 01246-904 - São Paulo, SP - Brazil
The progressive increase in the incidence of cardiovascular disease in developed countries in the XXth century has led to the rapid development of studies of this condition, in particular its etiopathology. In most industrialized countries this group of diseases, with ischemic cardiopathy and coronary disease in the foreground, has become a major cause of death over the last decades ${ }^{1}$.

In all of Brazil, the major cause of deaths is circulatory diseases, which comprise an unequal set of very different etiologies and clinical manifestations. Its major components are coronary and cerebrovascular diseases and cardiac failure, whose etiologies remain undetermined ${ }^{2}$.

Epidemiological studies of populations in their natural environment, with a follow-up of several years, have identified certain characteristics and personal habits strongly related to the probability of the onset of cardiovascular disease. These factors have generically been called risk factors and may or may not be amenable to intervention. Among the first, are smoking ${ }^{3}$, lack of physical activity ${ }^{4}$, diet ${ }^{5-9}$, hypertension ${ }^{10}$, hypercholesterolemia ${ }^{11}$, glucose intolerance ${ }^{12,13}$, and obesity ${ }^{13,14}$. Factors nonamenable to control are aging ${ }^{15}$, sex (male) ${ }^{1}$, race, and heredity ${ }^{16}$.

Available evidence demonstrates that children with cholesterol levels in the highest band of the normal distribution curve tend to become hypercholesterolemic adults ${ }^{17}$. Individuals, who in their infancy have high normal blood pressure levels in general become hypertensive adults ${ }^{18}$. In the same manner, a large number of individuals, who in their infancy exhibit levels of glycemia in the upper level of normalcy become diabetic adults ${ }^{19}$.

In general, a genetic predisposition for the development of these alterations exists. However, this predisposition appears to play a permissive rather than determinant role in the majority of cases where exposure to an inadequate life style is observed ${ }^{20}$.

Wynder at al. ${ }^{21}$ emphasize that to assure a healthy childhood and to avoid future cardiovascular disease, preventive health programs need to be adopted as early as 
possible. The fact that younger individuals are still shaping their life habits aids in their adherence to suggestions for changes aimed at a healthy life style. Bearing this in mind, the present study-describes the lipid profile of its subjects and associates it to other risk factors for cardiovascular disease in a population of young nutrition students.

\section{Methods}

A transversal study made during the 1997-1998 school year evaluated all students aged between 17 and 25 years studying nutrition at a public university in the State of São Paulo, Brazil. Twelve of the students did not permit collection of their blood, and 21 refused to participate in the study; 118 students did take part in the study. All answered a questionnaire about their life style, diet, and demographic characteristics. For some of the analyses, students were divided in 2 groups, aged between 17 and 19 years and between 20 and 35 years, respectively, according to lipid profile reference values ${ }^{22}$.

We analyzed the following variables: age (years completed), total cholesterol, low density lipoprotein cholesterol (LDL-C), high density lipoprotein cholesterol (HDL-C), triglycerides, family history (in which positive values were attributed to the presence of manifest atherosclerotic disease in first degree relatives, occurrence of coronary artery, cerebrovascular, or peripheral disease, or all of these, prior to 55 years of age in males, and 65 years of age in females) ${ }^{22}$, smoking (consumption of 3 or more cigarettes per day for a year or longer) ${ }^{23}$, use of contraceptive drugs (yes/no), body mass index (evaluated according to WHO recommendations) ${ }^{24}$, sedentariness (subjects were considered nonsedentary when participating in physical exercise at least twice a week for 30 min per session). Using the RJL ${ }^{\circledR}$ apparatus, bioimpedance was measured to obtain percentage of fat and lean body mass of the subjects.

Food consumption was evaluated from a 3-day food record. Specific software ${ }^{25}$ was used to analyze the food's energy, protein, total lipid, saturated lipid, fiber, cholesterol, sodium, and iron contents.

Statistical analyses were performed using the EPi Info, $6.04 \mathrm{c}$ version Program ${ }^{26}$. The possible association between risk factors for cardiovascular disease (body mass index, sedentariness, positive family history, use of contraceptive drugs, smoking, body fat, and lean body mass) and age group was evaluated by the chi-square association test, using Yates' correction for continuity ${ }^{27}$. To characterize lipid profile relative to age, mean values of risk factors for cardiovascular disease were compared using Student's t test when variables were homogeneous and by nonparametric (Mann-Whitney or Kruskal-Wallis) tests when heterogeneous ${ }^{28}$.

\section{Results}

Of the 118 female students analyzed, $38(32.2 \%)$ were between 17 and 19 , and $80(67.8 \%)$ between 20 - and 25-years of age. Mean age of the group was $20.28 \pm 1.58$ years.
Tables I and II present mean values of total cholesterol, HDL-C, LDL-C and triglycerides, according to the different categories of the variables under study. Compared with nonusers, total cholesterol levels were significantly higher $(\mathrm{P}=0.048)$ in the group using contraceptive drugs; this difference was also observed regarding average HDL-C levels of users versus nonusers of such drugs $(\mathrm{P}=0.031)$. Six $(5 \%)$ of the subjects had LDL-C:HDL-C ratios higher $(>5)$ than recommended. A statistically significant difference was noted following the comparison between triglyceride levels and percent lean body mass, subjects having the lowest triglyceride levels with the highest percentage of lean body mass $(\mathrm{P}=0.020)$. Table III indicates the existence of a statistically significant association between age and, respectively, total cholesterol $(\mathrm{P}=0.03)$, $\mathrm{LDL}-\mathrm{C}(\mathrm{P}=0.002)$, triglycerides $(\mathrm{P}=0.007)$, and percent body fat $(\mathrm{P}=0.026)$. Of 17- to 19 -year-old students, $34 \%$ had increased total cholesterol; for the 20-25-year age group, this percentage dropped to $10 \%$. Twenty-four percent of the 17- to19-year age group had increases in LDL-C, but for the 20- to 25-year group this ratio was only $4 \%$. Triglyceride values were increased in $24 \%$ of the students between 17 and 19 years of age, but in the older group this relation was 5\%. It should be pointed out that the reference values proposed by GEPA ${ }^{22}$ are more rigid for the younger group in comparison with individuals $\geq 20$ years old. Percent body fat was ideal in only $24 \%$ of the 17 - to 19 -year-old students, but between 20 and 25 years, this percentage increased to $48 \%$.

Relative to diet table IV shows the average amounts of energy, macro, and micronutrients consumed by the subjects, according to age group. No statistically significant differences between averages for energy or nutrients were observed. According to the percent macronutrient distribution relative to total caloric value, it could be observed that lipid and protein consumption overstepped recommended values. The amounts of these macronutrients were higher among 17- to 19-year-old students, having, respectively, 34 and $16 \%$ of the total caloric intake. On the other hand, values of protein consumption at 20-25 years were at the upper recommended limit (15\%) and overstepped the values recommended for lipids (32\%), although to a lesser extent. Concerning carbohydrate intake, both groups stayed within recommended values, at $50 \%$ of total caloric intake for the 17 - to 19-year-old age group and 53\% for the older group. Carbohydrate consumption remained at the lower recommended value $(50 \%)$.

The amount of sodium in the students' diets was much higher (420\%) than recommended. Iron consumption was not high enough to reach the recommended level. Subjects between 17 and 19 and 20 and 25 years had an adequacy of 77 and $66 \%$, respectively. Fiber consumption had the lowest level of adequacy among the population studied $(51 \%)$. Yet, the 17- to 19-year-old students' diets contained more fiber $(13.24 \mathrm{~g})$ relative to that of the older age group $(12.56 \mathrm{~g})$. These amounts represent in sequence, $53 \%$ and $50 \%$ adequacy. 


\begin{tabular}{|c|c|c|c|c|c|c|c|}
\hline \multirow{2}{*}{ Variable } & \multirow{2}{*}{ Category } & \multicolumn{3}{|c|}{ Cholesterol } & \multicolumn{3}{|c|}{ HDL-cholesterol } \\
\hline & & Mean & (SD) & $\mathrm{P}$ & Mean & (SD) & $\mathrm{P}$ \\
\hline BMI & $\begin{array}{c}<18,48 \quad(\mathrm{n}=10) \\
18.5-24.99 \quad(\mathrm{n}=98) \\
>25(\mathrm{n}=10)\end{array}$ & $\begin{array}{l}159.0 \\
162.1 \\
154.7\end{array}$ & $\begin{array}{l}(26.44) \\
(32.45) \\
(28.90)\end{array}$ & $0.709^{\mathrm{K}}$ & $\begin{array}{l}45.7 \\
45.8 \\
43.5\end{array}$ & $\begin{array}{c}(11.69) \\
(9.46) \\
(10.57)\end{array}$ & $0.603^{\mathrm{K}}$ \\
\hline Sedentariness & $\begin{array}{r}\text { Present }(\mathrm{n}=76) \\
\text { Absent }(\mathrm{n}=42)\end{array}$ & $\begin{array}{l}160.3 \\
161.7\end{array}$ & $\begin{array}{r}(29.29) \\
(32.92)\end{array}$ & $0.717^{\mathrm{M}}$ & $\begin{array}{r}43.9 \\
46.6\end{array}$ & $\begin{array}{l}(8.25) \\
(10.31)\end{array}$ & $0.159^{\mathrm{M}}$ \\
\hline Family history & $\begin{array}{r}\text { Present }(\mathrm{n}=46) \\
\text { Absent }(\mathrm{n}=72)\end{array}$ & $\begin{array}{l}157.8 \\
163.4\end{array}$ & $\begin{array}{l}(35.02) \\
(29.18)\end{array}$ & $0.099^{\mathrm{M}}$ & $\begin{array}{l}44.4 \\
46.4\end{array}$ & $\begin{array}{l}(9.71) \\
(9.65)\end{array}$ & $0.291^{\mathrm{M}}$ \\
\hline $\begin{array}{l}\text { Use of contraceptive } \\
\text { drugs }\end{array}$ & $\begin{array}{l}\text { Present }(\mathrm{n}=24) \\
\text { Absent }(\mathrm{n}=94)\end{array}$ & $\begin{array}{l}168.5 \\
159.3\end{array}$ & $\begin{array}{l}(24.55) \\
(32.96)\end{array}$ & $0.048^{\mathrm{M}}$ & $\begin{array}{l}49.3 \\
44.7\end{array}$ & $\begin{array}{l}(10.20) \\
(9.37)\end{array}$ & $0.031^{\mathrm{M}}$ \\
\hline Smoking & $\begin{array}{l}\text { Present }(n=8) \\
\text { Absent }(n=110\end{array}$ & $\begin{array}{l}167.4 \\
160.8\end{array}$ & $\begin{array}{l}(35.03) \\
(31.42)\end{array}$ & $0.578^{\mathrm{M}}$ & $\begin{array}{l}42.3 \\
45.9\end{array}$ & $\begin{array}{l}(6.04) \\
(9.87)\end{array}$ & $0.374^{\mathrm{M}}$ \\
\hline Body fat & $\begin{array}{c}>26 \%(\mathrm{n}=57) \\
<20 \%(\mathrm{n}=14) \\
20 \%-26 \%(\mathrm{n}=47)\end{array}$ & $\begin{array}{l}167.2 \\
147.1 \\
158.2\end{array}$ & $\begin{array}{l}(34.78) \\
(23.39) \\
(28.14)\end{array}$ & $0.051^{\mathrm{K}}$ & $\begin{array}{l}46.2 \\
43.4 \\
45.6\end{array}$ & $\begin{array}{l}(9.88) \\
(9.33) \\
(9.65)\end{array}$ & $0.697^{\mathrm{K}}$ \\
\hline Lean mass & $\begin{array}{c}>80 \%(\mathrm{n}=18) \\
<74 \%(\mathrm{n}=50) \\
74 \%-80 \%(\mathrm{n}=50)\end{array}$ & $\begin{array}{l}147.2 \\
166.8 \\
160.7\end{array}$ & $\begin{array}{l}(22.09) \\
(34.98) \\
(29.67)\end{array}$ & $0.060^{\mathrm{K}}$ & $\begin{array}{l}43.3 \\
46.1 \\
46.0\end{array}$ & $\begin{array}{c}(8.45) \\
(10.40) \\
(9.41)\end{array}$ & $0.611^{\mathrm{K}}$ \\
\hline
\end{tabular}

\begin{tabular}{|c|c|c|c|c|c|c|c|}
\hline \multirow[t]{2}{*}{ Variable } & \multirow[t]{2}{*}{ Category } & \multicolumn{3}{|c|}{ LDL-cholesterol } & \multicolumn{3}{|c|}{ Triglycerides } \\
\hline & & Mean & $(\mathrm{SD})^{1}$ & $\mathrm{p}^{2}$ & Média & $(\mathrm{SD})^{1}$ & $\mathrm{p}^{2}$ \\
\hline BMI & $\begin{array}{c}<18.48(\mathrm{n}=10) \\
18.5-24.99(\mathrm{n}=98) \\
>25(\mathrm{n}=10)\end{array}$ & $\begin{array}{l}90.3 \\
92.7 \\
88.3\end{array}$ & $\begin{array}{l}(28.74) \\
(25.86) \\
(22.19)\end{array}$ & $0.748^{\mathrm{K}}$ & $\begin{array}{l}114.9 \\
114.4 \\
114.2\end{array}$ & $\begin{array}{l}(43.78) \\
(35.39) \\
(50.60)\end{array}$ & $0.953^{\mathrm{K}}$ \\
\hline Sedentariness & $\begin{array}{l}\text { Present }(n=76) \\
\text { Absent }(n=42)\end{array}$ & $\begin{array}{l}92.8 \\
91.8\end{array}$ & $\begin{array}{l}(25.67) \\
(25.79)\end{array}$ & $0.991^{\mathrm{M}}$ & $\begin{array}{l}116.9 \\
113.1\end{array}$ & $\begin{array}{l}(36.00) \\
(37.99)\end{array}$ & $0.717^{\mathrm{M}}$ \\
\hline Family history & $\begin{array}{l}\text { Present }(\mathrm{n}=46) \\
\text { Absent }(\mathrm{n}=72)\end{array}$ & $\begin{array}{l}89.2 \\
94.0\end{array}$ & $\begin{array}{l}(27.52) \\
(24.38)\end{array}$ & $0.137^{\mathrm{M}}$ & $\begin{array}{l}120.3 \\
110.7\end{array}$ & $\begin{array}{l}(37.80) \\
(36.56)\end{array}$ & $0.214^{\mathrm{M}}$ \\
\hline $\begin{array}{l}\text { Use of } \\
\text { Contraceptive drugs }\end{array}$ & $\begin{array}{l}\text { Present }(\mathrm{n}=94) \\
\text { Absent }(\mathrm{n}=24)\end{array}$ & $\begin{array}{l}94.6 \\
91.5\end{array}$ & $\begin{array}{l}(21.21) \\
(26.72)\end{array}$ & $0.293^{\mathrm{M}}$ & $\begin{array}{l}123.7 \\
112.1\end{array}$ & $\begin{array}{l}(33.09) \\
(37.95)\end{array}$ & $0.067^{\mathrm{M}}$ \\
\hline Smoking & $\begin{array}{c}\text { Present }(n=8) \\
\text { Absent }(n=110)\end{array}$ & $\begin{array}{l}99.5 \\
91.6\end{array}$ & $\begin{array}{l}(28.45) \\
(25.48)\end{array}$ & $0.486^{\mathrm{M}}$ & $\begin{array}{l}128.9 \\
113.4\end{array}$ & $\begin{array}{l}(49.14) \\
(36.23)\end{array}$ & $0.335^{\mathrm{M}}$ \\
\hline Body fat & $\begin{array}{c}>26 \%(\mathrm{n}=57) \\
<20 \%(\mathrm{n}=14) \\
20 \%-26 \%(\mathrm{n}=47)\end{array}$ & $\begin{array}{l}96.6 \\
83.0 \\
89.4\end{array}$ & $\begin{array}{l}(27.47) \\
(26.36) \\
(22.34)\end{array}$ & $0.100^{\mathrm{K}}$ & $\begin{array}{l}115.4 \\
103.6 \\
116.4\end{array}$ & $\begin{array}{l}(36.33) \\
(41.40) \\
(37.21)\end{array}$ & $0.217^{\mathrm{K}}$ \\
\hline Lean mass & $\begin{array}{c}>80 \%(\mathrm{n}=18) \\
<74 \%(\mathrm{n}=50) \\
74 \%-80 \%(\mathrm{n}=50)\end{array}$ & $\begin{array}{l}84.1 \\
96.5 \\
90.7\end{array}$ & $\begin{array}{l}(24.36) \\
(27.70) \\
(23.48)\end{array}$ & $0.144^{\mathrm{K}}$ & $\begin{array}{c}98.5 \\
113.5 \\
121.1\end{array}$ & $\begin{array}{l}(38.81) \\
(35.98) \\
(36.67)\end{array}$ & $0.020^{\mathrm{K}}$ \\
\hline
\end{tabular}

\section{Discussion}

Mortality due to cardiovascular disease in major Brazilian cities is similar to that in other countries ${ }^{29}$. To reverse this picture, the adoption of preventive measures has been shown to be more efficient than any form of therapeutic intervention ${ }^{30}$. Understanding the extent of the various risk factors of cardiovascular disease and their identification among different age groups is essential for effective prevention planning. Furthermore, adequacy of the plan for the reality of the place of implementation is fundamental.
The data of the present study, taken together with other data found in the literature, indicate a high prevalence of risk factors in young individuals. Rabelo et al. ${ }^{31}$, in an evaluation of atherosclerotic risk factors in 209 university students of either sex, aged between 17 and 19 years, verified that the most prevalent risk factor was sedentariness (78.9\%). Increased levels of total cholesterol and LDL-C occurred in 9.1 and $7.6 \%$ of the sample, respectively; decreases in HDL-C were observed in $8.6 \%$ of the subjects; increased triglyceride levels in $16.3 \%$, smoking in $15.65 \%$ and a positive family history of ischemic heart disease in 
19.6\%. Forti et al. ${ }^{32}$ in an evaluation of adolescent offspring of young (12 to 19 years old) cardiopaths, observed that $44.6 \%$ had higher than ideal values of total cholesterol and LDL-C. Overweight and obesity were present in 13.2 and 15.8 percent of the cases, respectively, and smoking in $10.4 \%$.

A statistically significant association between serum cholesterol and use of contraceptive drugs was found. Most of the users were of the 20- to 25-year age group. This result suggests that the use of contraceptives predominates after adolescence. It is known that progesterone drugs having a

\begin{tabular}{|c|c|c|c|c|c|c|}
\hline \multicolumn{7}{|c|}{$\begin{array}{c}\text { Table III - Number and percentage of students according to age } \\
\text { and other variables studied }\end{array}$} \\
\hline \multirow[t]{2}{*}{ Variable } & \multirow[t]{2}{*}{ Category } & \multicolumn{2}{|c|}{ 17-19 Years } & \multicolumn{2}{|c|}{ 20-25 Years } & \multirow[t]{2}{*}{$\mathrm{P}$} \\
\hline & & $\mathrm{N}^{\circ}$ & $\%$ & $\mathrm{~N}^{\mathrm{o}}$ & $\%$ & \\
\hline \multirow[t]{2}{*}{ Smoking } & Present & 03 & 7.9 & 05 & 6.3 & 0.952 \\
\hline & Absent & 35 & 92.1 & 75 & 93.8 & \\
\hline \multirow[t]{2}{*}{ Sedentariness } & Present & 10 & 26.3 & 32 & 40.0 & 0.213 \\
\hline & Absent & 28 & 73.7 & 48 & 60.0 & \\
\hline \multirow[t]{2}{*}{ Family history } & Present & 15 & 39.5 & 31 & 38.8 & 0.899 \\
\hline & Absent & 23 & 60.5 & 49 & 61.3 & \\
\hline \multirow[t]{2}{*}{ Use of contraceptives } & s Present & 6 & 15.8 & 18 & 22.5 & 0.548 \\
\hline & Absent & 32 & 84.2 & 62 & 77.5 & \\
\hline \multirow[t]{2}{*}{ Total cholesterol } & Increased & 13 & 34.2 & 08 & 10.0 & 0.003 \\
\hline & Desirable & 25 & 65.8 & 72 & 90.0 & \\
\hline \multirow[t]{2}{*}{ HDL-c } & Desirable & 31 & 81.6 & 74 & 92.5 & 0.145 \\
\hline & Decreased & 7 & 18.4 & 06 & 7.5 & \\
\hline \multirow[t]{2}{*}{ LDL-c } & Desirable & 29 & 76.3 & 77 & 96.3 & 0.002 \\
\hline & Increased & 9 & 23.7 & 03 & 3.8 & \\
\hline \multirow[t]{2}{*}{ Triglycerides } & Increased & 9 & 23.7 & 04 & 5.0 & 0.007 \\
\hline & Desirable & 29 & 76.3 & 76 & 95.0 & \\
\hline \multirow[t]{3}{*}{ Body mass index } & $<18,48$ & 2 & 5.3 & 08 & 10.0 & \\
\hline & $18.5-24.99$ & 31 & 81.6 & 67 & 83.8 & 0.342 \\
\hline & $>25$ & 05 & 13.2 & 05 & 6,3 & \\
\hline \multirow[t]{3}{*}{ Body fat } & $>26 \%$ & 25 & 65.8 & 32 & 40.0 & 0.026 \\
\hline & $<20 \%$ & 4 & 10.5 & 10 & 12.5 & \\
\hline & $20 \%-26 \%$ & 9 & 23.7 & 38 & 47.5 & \\
\hline \multirow[t]{3}{*}{ Lean mass } & $>80 \%$ & 6 & 15.8 & 12 & 15.0 & 0.230 \\
\hline & $<74 \%$ & 20 & 52.6 & 30 & 37.5 & \\
\hline & $74 \%-80 \%$ & 12 & 31.6 & 38 & 47.5 & \\
\hline \multicolumn{2}{|l|}{ Total } & 38 & 100 & 80 & 100 & \\
\hline
\end{tabular}

higher androgen potential can lower the protective effect of estrogen drugs. Recently, new progesterone drugs designed with the objective of non-interference with the lipid profile (desogestrel and gestogen) have reached the market. However, the present diversity of contraceptive drugs of various types and dosage levels may interfere in the analysis of lipoprotein alterations in contraceptive users. Because in the present study the compositions of the contraceptive drugs used was not questioned, the analysis of their effects remains limited.

A statistically limited association between serum cholesterol levels and body composition was noted, illustrating the importance of this index of evaluation. In spite of the prevalence of overweight subjects, $48.3 \%$ of the students had an increased percentage of body fat and $42.4 \%$ had a decreased percentage of lean mass. Lower mean triglyceride values were associated with higher percent values of lean mass. These data can be explained by the high prevalence of sedentariness (35.6\%) among the students, not associated with the lipid profile; however, it directly influenced body composition. Because a sedentary life style is an independent cardiovascular disease risk factor $^{33}$, the Healthy People 2000 Program recommends regular, preferably daily physical activity for at least $30 \mathrm{~min}$ for individuals from six years of age up ${ }^{34}$.

The evaluation of diet composition showed low carbohydrate and high lipid consumption by the subjects. The tendency to reduce consumption of cereals and tubers, of substituting carbohydrates for lipids, and exchanging vegetable for animal protein is part of a changed dietary pattern that may reduce weight gain and its detrimental effects ${ }^{35}$.

Diet is considered one of the most important environmental variables involved in the shaping of lipid profiles ${ }^{36}$. Excessive high fat and cholesterol intake is associated with increased serum levels of total and LDL-cholesterol ${ }^{37,38}$. In the present study, the worst distribution of macronutrient proportions was found in students aged between 17 and 19 years. It has not yet been possible to correlate lipoprotein alterations with inadequate ingestion of fat and cholesterol. However, these students had average total cholesterol,

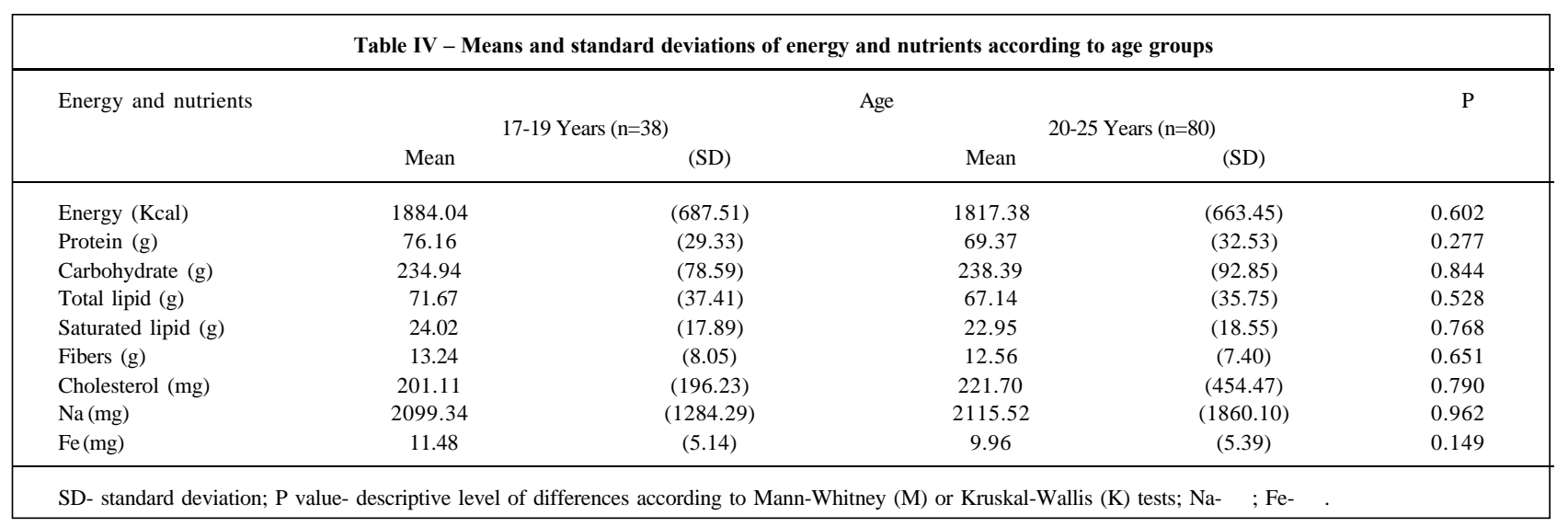


LDL-cholesterol, and triglyceride levels statistically higher than those of the 20 to 25 year age group. The association between diet and serum lipid levels becomes clearer from the results of studies aimed at the comparison between different populations as shown by the Seven Countries Study ${ }^{39}$. In this work, the strong association between fat ingestion and serum cholesterol levels, verified upon comparing different cohorts, was not observed in any particular cohort. As mentioned by Dressler et al. ${ }^{40}$ interindividual variability, both regarding diet as well as serum levels of cholesterol, may reduce the possibility of detecting the presence of an association within the same population. However, obtaining averages from many individuals, allowing for the demonstration of possible associations when comparing different populations, can minimize random variation.

The present study calls to attention alterations of lipid profiles and their association with ischemic heart disease risk factors in young nutrition students, who maintained their life style despite knowledge acquired during their formative years. University involvement, not only in the evaluation of the risk profiles of students and staff, but also in the educational process, explaining the benefits consequent to the adoption of a healthier life style, would be of great value for the establishment of preventive planning in their institutions.

\section{References}

1. Laurenti R, Lolio CA. Cardiopatia isquêmica no Brasil. Considerações epidemiológicas. In: Carvalho VB, Macroz R. Cardiopatia isquêmica - aspectos de importância clínica. $1^{\text {a }}$ ed. São Paulo: Savier, 1989.

2. Ministério da Saúde. Estatísticas de Mortalidade - 1989. Brasília (DF), 1993.

3. Pathobiological Determinants of Atherosclerosis in Youth (PDAY) Research Group. Relationship of atherosclerosis in young men serum lipoprotein colesterol concentrations and smoking. JAMA 1990; 246: 3018-23.

4. Shaw LW. Effects of a prescribed supervised exercise program on mortality and cardiovascular morbidity in patients after myocardial infaction. Am J Cardiology $1981 ; 48: 39-42$

5. Bao W, Srinivasan SR, Wattigney WA, Berenson GS. The relation of parenteral cardiovascular disease to risk factors in children and young adults. Circulation 1995; 91: 365-71.

6. Bennett SA, Magnus P. Trends in cardiovascular risk factors in Australia. Med J Aust 1994; 161: 519-27.

7. Mcnamara DJ, Howell WH. Epidemiologic data linking diet to hiperlipidemia and atheriosclerosis. Sem Liver Dis 1992; 12: 347-55.

8. Popkin BM, Haines PS, Petterson RE. Dietary changes in older Americans, 1977-1987. Am J Clin Nutr 1992; 55: 823-30.

9. Woo J, Ho SC, Chan SG, Sham A, Yuen YK, Masarei JL. Lipid profile in the Chinese old-old: comparation with younger age groups and relationship with some cardiovascular risk factors and presence of diseases. Cardiology 1993; 83: 407-14.

10. Kannel WB. Role of blood pressure in cardiovascular disease. The Framingham Study. Angiology 1975; 26: 1-14.

11. Stamler JR, Wentworth D, Neaton JD. Is the relationship between serum cholesterol and risk of death from coronary heart continuouns and graded? Findings in 356,222 primary screenees of the Multiple Risk Factor Intervention Trial (MRFIT). JAMA. 1986; 256: 2823-8.

12. Fuller JN, Shipley MJ, Rose G, Jarrett, RJ, Keen H. Coronary heart disease risk and impaired glucose tolerance. The Whitehall Study. Lancet 1980; 1: 1373-9.

13. Jeffery RW, Wing RR, French SA. Weight cycling and cardiovascular risk factors in obese men and women. Am J Clin Nutr 1992; 55: 641-4.

14. Hubert HB, Feinleib M, McNamara PM, Castelli WP. Obesity as an independent risk factor for cardiovascular disease: a 26 year follow-up of participants in the Framingham Heart Study. Circulation 1983; 67: 968-77.

15. Giannini SD. Aterosclerose no idoso: fundamentos para sua prevenção. Rev Bras Med 1985; 4: 303-6.

16. Barret-Connor E, Khaw K. Family history of heart attack as an independent predictor of death due to cardiovascular disease. Circulation 1984; 69: 1065-9.

17. Frerichs RR, Webber LS, Voors AW, Srinivasan SR, Berenson GS. Cardiovascular disease risk factor variables in children at two successive years: the Bogalusa heart study. J Chronic Dis 1979; 32: 251-62.

18. Leitschuh M, Cupples LA, Kannel W, Gagnon D, Chobanian A. High normal blood pressure progression to hypertension in the Framigham Heart Study. Hypertension 1991; 17: 22-7.

19. Wilson PW, McGee DL, Kannel WB. Obesity, very low density lipoproteins, and glucose intolerance over fourteen years: The Framingham Study. Am J Epidemiol 1981; 114: 697-704.
20. Kannel WB, D'Agostino RB, Belanger AJ. Concept of bridging the gap from youth to adulthood. Am J Med Scienc 1995; 310(suppl 1): S15 - S21.

21. Wynder EL, Berenson GS, Strong WB, Williams C. Coronary artery disease prevention: cholesterol. A pediatric perspective. Prev Med 1989; 18: 323-409.

22. Grupo de Estudos e Pesquisa em Aterosclerose (GEPA). Segundo Consenso Brasileiro sobre Dislipidemias: detecção, avaliação e tratamento. Arq Bras Cardiol 1996; 67: 1-16.

23. La Vecchia C, Francheschi S, Decarli A, Fasoli M, Gentiule A, Tognoni G. Cigarette smoking and risk of cervical neoplasia. Am J Epidemiol 1986; 123: $365-74$.

24. World Health Organization (WHO). Physical Status: the use and interpretation of anthopometry. Geneve, WHO, 1995. (Technical Report Series, 841).

25. Philippi ST, Szarfarc SC, Latterza AR. Virtual Nutri (software) versão 1.0, for Windows. Departamento de Nutrição da Faculdade de Saúde Pública - USP. São Paulo, 1996.

26. Centers for Disease Control, World Health Organization. Epi Info. Epidemiologia em microcomputadores: um sistema de processamento de texto, banco de dados e estatísticas [software]. Versão 6.04c. Atlanta: OPAS/ WHO, 1990.

27. Berquó ES, Gotlieb SLD, Pacheco JF. Bioestatística. São Paulo: EPU, 1981.

28. Siegel S. Estatística não paramétrica. Rio de Janeiro: Ncgraw-Hill, 1975.

29. Lotufo PA. A mortalidade precoce por doenças crônicas em capitais de áreas Metropolitanas do Brasil. Tese de Doutoramento, Faculdade de Saúde Pública USP. São Paulo, 1996.

30. Lefant C, Savage PJ. The early natural history of atherosclerosis and hypertension in the young: National Institutes of Health Perspectives. Am J Med Scienc 1995; 310(suppl 1): S3-7.

31. Rabelo LM, Viana RM, Schimith MA, et al. Risk factors for atherosclerosis in students of a private University in São Paulo - Brazil. Arq Bras Cardiol 1999; 72: 575-80.

32. Forti N, Giannini SD, Diament J, et al. Fatores de risco para doença arterial coronariana em crianças e adolescentes filhos de cardiopatas jovens. Arq Bras Cariol 1996; 66: 119-23.

33. Rowland TW, Freedson PS. Physical activity, fitness, and health in children: a close look. Pediatrics 1994; 93: 669-72.

34. Bronfin DR, Urbina EM. The role of the pediatrician in the promotion of cardiovascular health. Am J Med Scienc 1995; 310(suppl 1): S42-S7.

35. Monteiro CA, Mondini L, de Souza AL, Popkin BM. The nutrition transition in Brazil. Eur J Clin Nutr 1995; 49: 105-13.

36. Nicklas TA. Dietary studies of children and young adults (1973 - 1988): the Bogalusa Heart Study. Am J Med Scienc 1995; 310(suppl 1): S101-8.

37. Grundy SM. Dietary therapy of hyperlipidemia. In: Gabello WJ. Slide Atlas of Lipid Disorders. $3^{\mathrm{a}}$ ed. New York: Gower Medical Publishing, 1990: 35.

38. Shekelle RB, Shryock AM, Oblesby P. Diet, serum cholesterol, and death from coronary heart disease: the Western Eletric Study. N Engl J Med 1981; 304: 65-70.

39. Keys A, Menotti A, Karvonen MJ, et al. The diet and 15-year death rate in the Seven Coutries Study. Am J Epidemiol 1986; 124: 903-15.

40. Dressler WW, Santos JE, Viteri FE, Gallagher Jr PN. Social and dietary predictors of serum lipids: a brazilian example. Soc Sci Med 1991; 32: 1229-35. 